\title{
Online System dalam Pengelolaan Bank Sampah - Studi Kasus: Kabupaten Bekasi
}

\author{
Dadi Rusdiana(1), An Nisa'a Siti Humaira(2) \\ (1). Staf Pengajar, Program Studi Perencanaan Wilayah dan Kota, ITSB. dadi.kyute@gmail.com \\ (2.) Staf Pengajar, Program Studi Perencanaan Wilayah dan Kota, ITSB. annisaa.sitihumaira@gmail.com
}

\begin{abstract}
Abstrak
Bank sampah merupakan salah satu program pengurangan sampah nasional. Dalam pelaksanaannya terdapat sejumlah kendala seperti kurang praktisnya transaksi antara nasabah dengan pengelola yang seringkali membuat masyarakat kurang tertarik dengan bank sampah. Dalam merespon tantangan tersebut, pengembangan aplikasi online bank sampah saat ini telah dilakukan dengan harapan memberikan kemudahan dalam pengelolaan dan transaksi kepada masyarakat, baik sebagai nasabah, maupun sebagai pengelola bank sampah. Bank sampah mulai berkembang mulai tahun 2008 hingga tahun 2016, sudah tercatat ada 163.878 nasabah bank sampah di 5.244 bank sampah di Indonesia. Telah ada beberapa platform online untuk penyelenggaraan/mendukung penyelenggaraan bank sampah di Indonesia yang diantaranya adalah Smash, Gringgo, Angkuts, SIMALU dan OBABAS. Platform online yang telah memiliki jangkauan pelayanan di Kabupaten Bekasi adalah Smash. Tujuan dari penelitian yang dilaksanakan adalah untuk mengidentifikasi sistem pengelolaan bank sampah berbasis platform online. Dalam sistem pengelolaan sampah secara umum, perbedaan yang terjadi antara sistem pembelian sampah yang diterapkan oleh bank sampah yang sudah dan belum tergabung dengan sistem online adalah pada variabel peminjaman uang, dampak partisipasi dalam sistem online (Smash), keberadaan fasilitator, kegiatan di luar jual beli sampah, kegiatan pengolahan sampah dan sistem bagi hasil. Dengan teridentifikasinya kondisi penyelenggaraan bank sampah baik secara konvensional dan online, maka dapat diketahui perbedaan pengelolaan antara kedua sistem tersebut sehingga dapat mendukung peningkatan kinerja bank sampah online ke depannya yang dapat diimplementasikan oleh pemerintah pusat maupun daerah, komunitas/penggiat lingkungan, sektor privat dan juga masyarakat secara umum.
\end{abstract}

Kata-Kunci: Sampah, 3R, Bank Sampah, Sistem Bank Sampah Online

\begin{abstract}
The Waste bank is one of the national waste reduction programs. In its implementation, there are several obstacles such as the lack of practical transactions between customers and managers which often makes people less interested in waste banks. In responding to these challenges, the development of online garbage bank applications has now been carried out in the hope of providing convenience in management and transactions to the public, both as customers and as managers of waste banks. Waste banks began to develop from 2008 to 2016, there were already 163,878 garbage bank customers in 5,244 waste banks in Indonesia. There have been several online platforms for organizing /supporting the operation of waste banks in Indonesia, including Smash, Gringgo, Angkuts, SIMALU, and OBABAS. The online platform that already has a range of services in the Bekasi Regency is Smash. The purpose of the research carried out is to identify the online platform based waste management system. In the general waste management system, the differences that occur between the waste purchasing system implemented by the garbage bank that have and have not been incorporated into the online system are the variables of money lending, the impact of participation in the online system (Smash), the presence of facilitators, activities outside the sale and purchase waste, waste management activities, and profit-sharing system. With the identification of the conditions for managing waste banks both conventionally and online, it can be seen the differences in management between the two systems so that they can support the improvement of online garbage bank performance going forward that can be implemented by the central and regional governments, the community / environmental activists, the private sector and also the community generally.
\end{abstract}

Keywords: Waste, 3R, Waste Bank, Online Waste Bank System 


\section{PENGANTAR}

Persoalan pengelolaan sampah di Indonesia berkutat pada terus meningkatkanya jumlah timbulan dan jenis sampah yang dipengaruhi oleh beberapa hal seperti petumbuhan jumlah penduduk, kemajuan teknologi, produk kemasan plastik lebih beragam, perubahan pola dan gaya hidup serta belum optimalnya pengelolaan sampah di tingkat kabupaten/kota (KLHK, 2017). KLHK (2017) juga menyatakan bahwa belum optimalnya pengelolaan sampah di kabupaten/kota disebabkan oleh kesadaran masyarakat terhadap sampah yang masih rendah, sarana-prasarana yang tidak memadai dan APBD pengelolaan sampah yang tergolong masih rendah. Meskipun didalam arahan kebijakan dan strategi nasional mengupayakan untuk mewujudkan kesehatan masyarakat dan lingkugan yang berkualitas dengan kebijakan pengurangan (30\% atau 20,9 juta ton sampah) dan penanganan sampah $(70 \%$ yang setara dengan 49,9 juta ton sampah) yang ditargetkan untuk tahun 2025 (KLHK, 2017).

Bank sampah ditujukan untuk merubah kebiasaan masyarakat untuk tidak membuang sampah sembarangan, membarikan edukasi kepada masyarakat agar mau memilah sampah dengan memberikan pengertian bahwa sampah mempunyai nilai ekonomi, pemanfaatan barang bekas yang lebih maksimal, serta mengurangi jumlah sampah yang terbuang. Bank sampah merupakan kegiatan social engineering yang mengajarkan masyarakat untuk memilah sampah serta menumbuhkan kesadaran masyarakat dalam pengolahan sampah secara bijak dan pada akhirnya akan mengurangi (reduce) sampah yang diangkut ke TPA.

Pengelolaan sampah melalui bank sampah tidaklah mudah, masih ditemui berbagai kendala dan persoalan teknis yang diantaranya adalah keterbatasan lahan untuk menampung sampah, terutama pada kawasan permukiman yang padat penduduk. Pada beberapa daerah, bantuan masih berupa peralatan untuk menunjang kegiatan bank sampah, sedangkan lahan harus disediakan oleh calon pengelola bank sampah tersebut. Masalah lainnya adalah kurang praktisnya transaksi antara nasabah dengan pengelola juga terkadang membuat masyarakat kurang tertarik dengan bank sampah.

Pengembangan aplikasi online bank sampah saat ini telah dilakukan dengan harapan memberikan kemudahan dalam pengelolaan dan transaksi kepada masyarakat, baik sebagai nasabah, maupun sebagai pengelola bank sampah. Sistem pengelolaan sampah online telah dikenalkan di berbagai daerah, salah satunya di Kabupaten Bekasi yang diperkenalkan sejak tahun 2018.

Pengelolaan secara online diharapkan dapat meningkatkan performa bank sampah menjadi lebih luas cakupannya tanpa harus membuka lahan baru untuk pengumpulan sampah. Sistem online dalam pengelolaan bank sampah diharapkan bisa dijadikan sebagai alat untuk melakukan rekayasa sosial dalam perwujudan 3R pada sumber produksi sampah.

Tujuan dari penelitian yang dilaksanakan adalah untuk mengidentifikasi bagaimana pengaruh sistem pengelolaan bank sampah berbasis platform online terhadap bank sampah konvensional.

\section{KAJIAN PUSTAKA}

\section{a. Pengertian Bank Sampah}

Menurut Peraturan Menteri Negara Lingkungan Hidup Republik Indonesia Nomor 13 Tahun 2012 tentang Pedoman Pelaksanaan Reduce, Reuse, dan Recycle melalui Bank Sampah, pada pasal 1 disebutkan bahwa Bank sampah adalah tempat pemilahan dan pengumpulan sampah yang dapat didaur ulang dan/atau diguna ulang yang memiliki nilai ekonomi.

Statistik perkembangan pembangunan Bank Sampah di Indonesia pada bulan Februari 2012 menunjukkan terdapat 471 buah jumlah Bank Sampah yang sudah berjalan dengan jumlah penabung sebanyak 47.125 orang dan jumlah sampah yang terkelola adalah $755.600 \mathrm{~kg} / \mathrm{bulan}$ dengan nilai perputaran uang sebesar Rp. 1.648.320.000 perbulan (buku profil bank sampah indonesi 2012). Angka statistik ini meningkat menjadi 886 buah Bank Sampah berjalan sesuai data bulan Mei 2012, dengan jumlah penabung sebanyak 84.623 orang dan jumlah sampah yang terkelola sebesar $2.001 .788 \mathrm{~kg} / \mathrm{bulan}$ serta menghasilkan uang sebesar $\mathrm{Rp}$. 3.182.281.000 perbulan. Data terbaru dari Kementerian Lingkungan Hidup bahwa per Agustus 2014 sebanyak 1.703 bank sampah dengan jumlah nasabah 100.002 orang 2.494.715 sampah yang terkelola serta menghasilkan 15.367.895.000 (Anis Indah Kurnia dan Dadang Romansyah, Jurnal Akuntansi dan Keuangan Islam 3, No. 1 (2015)). 


\section{b. Pendirian dan Pengembangan Bank Sampah}

Adapun tahapan - tahapan yang biasanya dilalui dalam pendirian bank sampah sampai berkembang (Unilever Indonesia, Buku Panduan Sistem Bank Sampah \& 10 Kisah Sukses, Jakarta, Unilever, 2014 h.8-9) adalah sebagi berikut:

- Sosialisasi

- Pelatihan Teknis

- Pelaksanaan Sistem Bank Sampah

- Pemantauan dan Evaluasi

- Pengembangan

\section{c. Persyaratan Bank Sampah}

Persyaratan bank sampah telah di atur dalam Peraturan Menteri Negara Lingkungan Hidup Republik Indonesia Nomor 13 Tahun 2012 Tentang Pedoman Pelaksanaan Reduce, Reuse, dan Recycle Melalui Bank Sampah, yaitu mengenai konstruksi dan standar manajemen.

\section{d. Pelaksanaan Bank Sampah}

Pelaksanaan bank sampah yang telah di atur oleh Peraturan Menteri Negara Lingkungan Hidup Republik Indonesia Nomor 13 Tahun 2012 Tentang Pedoman Pelaksanaan Reduce, Reuse, dan Recycle Melalui Bank Sampah adalah sebagai berikut.

- Jam kerja

- Penarikan tabungan

- Peminjaman uang

- Buku tabungan

- Jasa penjemputan sampah

- Jenis tabungan

- Jenis sampah

- Penetapan harga

- Kondisi sampah

- $\quad$ Berat minimum

- Wadah sampah

- Sistem bagi hasil

- Pemberian upah karyawan

\section{e. Mekanisme Sistem Bank Sampah}

Pengelolaan sampah berbasis bank sampah memberikan banyak manfaat bagi masyarakat. Keuntungan berupa kebersihan lingkungan, kesehatan, hingga ekonomi, berikut mekanisme kerja bank sampah (Unilever Indonesia, Buku Panduan Sistem Bank Sampah \& 10 Kisah Sukses, Jakarta, Unilever, 2014 h. 8-9).

- Pemilahan bank sampah rumah tangga

- Penyetoran sampah ke bank

- Penimbangan

- Pencatatan

- Pengangkutan

\section{METODE}

\section{a. Metode Pengumpulan Data}

Data dikumpulkan baik secara sekunder maupun primer. Pengumpulan data sekunder dilakukan dengan desk study yang meninjau data-data statistik, dokumen, kebijakan dan peraturan perundanga terkait dengan penyelenggaraan bank sampah yang sebagian besar dipublikasikan oleh pemerintah.

Sementara itu, data primer dikumpulkan baik dengan observasi maupun wawancara. Observasi terkait dengan lingkungan bank sampah dan ruang pelayanan bank sampah dilakukan terhadap 2 bank sampah di Kabupaten Bekasi yang terpilih menjadi sampel. Wawancara terhadap pengelola bank sampah juga dilakukan untuk mengetahui sistem pembelian sampah, sistem penjualan sampah dan sistem pengelolaan sampah secara umum. Wawancara tersebut dilakukan terhadap 2 pengelola bank sampah dan 1 perusahaan platform online untuk penyelenggaraan bank sampah.

Pemilihan objek observasi dan responden wawancara tersebut diperoleh dengan teknik purposive sampling. Purposive sampling adalah teknik pengambilan sampel sumber data dengan pertimbangan tertentu (Sugiyono, 2016). Alasan menggunakan teknik purposive sampling adalah karena tidak semua sampel memiliki kriteria yang sesuai dengan fenomena yang diteliti. Oleh karena itu, peneliti memilih teknik purposive sampling yang menetapkan pertimbanganpertimbangan atau kriteria-kriteria tertentu yang harus dipenuhi oleh sampel-sampel yang digunakan dalam penelitian ini.

Dalam penelitian ini yang menjadi sampel adalah bank sampah yang memenuhi kriteria tertentu. Adapun kriteria yang dijadikan sebagai sampel penelitian yaitu:

- Bank sampah konvensional (tidak menggunakan sistem online) di Kabupaten Bekasi;

- Bank sampah yang telah menggunakan sistem online dalam penyelenggaraannya di Kabupaten Bekasi; dan

- perusahaan penyelenggara bank sampah dengan platform online yang memiliki nasabah bank sampah di Kabupaten Bekasi.

\section{b. Metode Analisis Data}

Penelitian yang dilakukan menggunakan pendekatan kualitatif dengan metode analisis isi/konten dan metode deskriptif-eksploratif. 
Metode analisis isi (content analysis) menurut Krippendorff (1993) adalah "suatu teknik penelitian untuk membuat inferensi-inferensi yang dapat ditiru dan sahih data dengan memperhatikan konteksnya". Analisis ini digunakan sebagai metode dalam penelitian karena mempertimbangkan bentuk data dan informasi yang dikumpulkan berupa wawancara dan dokumen resmi yang memerlukan teknik untuk memahami dan menginterpretasikan data tersebut.

Metode analisis deskriptif-eksploratif dilakukan untuk menganalisis dan menyajikan data secara sistemik sehingga lebih mudah dipahami dan disimpulkan serta juga bertujuan untuk menemukan sesuatu yang baru yang berupa pengelompokkan suatu gejala/keadaan, fakta atau fenomena tertentu yang diamati.

\section{PEMBAHASAN DAN DISKUSI}

Untuk dapat mengetahui perbedaan praktik penyelenggaraan bank sampah konvensional dan yang telah berbasiskan online, maka dilakukan pengamatan antara 2 objek amatan baik untuk variabel lingkungan bank sampah, ruang pelayanan bank sampah, sistem pembelian sampah, sistem penjualan sampah dan sistem pengelolaan bank sampah secara umum. Bank sampah Permata di RT 01/RW 011 Desa Jatireja, Kecamatan Cikarang Timur, Kabupaten Bekasi merupakan bank sampah yang sudah tergabung ke dalam sistem online Smash sedangkan bank sampah Permata RT 05/RW 012 Desa Jatireja, Kecamatan Cikarang Timur, Kabupaten Bekasi belum tergabung ke dalam sistem online.

\section{a. Lingkungan Bank Sampah}

Secara fisik, kondisi lingkungan bank sampah yang sudah dan belum tergabung dengan sistem online tidak memiliki perbedaan yang cukup signifikan baik dari kondisi lantai, dinding, ventilasi, atap, langitlangit, pintu, halaman, pagar, taman, parkir dan drainase sekitar.

Tabel 1 Lingkungan Bank Sampah

\begin{tabular}{|c|c|c|c|}
\hline No & $\begin{array}{l}\text { Variabel } \\
\text { Amatan }\end{array}$ & $\begin{array}{c}\text { Bank Sampah Permata RT 01/RW } 011 \\
\text { (Sudah Tergabung dengan Sistem } \\
\text { Online) }\end{array}$ & $\begin{array}{c}\text { Bank Sampah Permata RT 05/RW } \\
012 \text { (Belum Tergabung dengan } \\
\text { Sistem Online) }\end{array}$ \\
\hline 1 & Lantai & $\begin{array}{l}\text { Lantai dari pos bank sampah ini terbagi } \\
\text { menjadi dua bagian yaitu: } \\
\text { a. lantai bangunan bagian dalam yang } \\
\text { telah ditutupi oleh keramik dengan } \\
\text { kondisi yang sudah cukup rusak } \\
\text { akibat barang berat maupun rusak } \\
\text { secara alami; } \\
\text { b. lantai bangunan bagian luar yang } \\
\text { dilapisi oleh pasir sehingga kondisi } \\
\text { pos bank sampah berdebu. }\end{array}$ & $\begin{array}{l}\text { Lantai dari pos bank sampah ini } \\
\text { terbagi menjadi dua bagian yaitu: } \\
\text { a. lantai bangunan bagian dalam } \\
\text { yang telah ditutupi oleh keramik } \\
\text { dengan kondisi yang sudah cukup } \\
\text { rusak akibat barang berat maupun } \\
\text { rusak secara alami; } \\
\text { b. lantai bangunan bagian luar yang } \\
\text { dilapisi oleh semen dengan } \\
\text { kondisi yang sudah cukup rusak } \\
\text { lapisannya. }\end{array}$ \\
\hline 2 & Dinding & $\begin{array}{l}\text { Dinding pos bank sampah ini masih } \\
\text { berdiri dengan cukup baik namun di } \\
\text { beberapa bagian mengalami } \\
\text { pengelupasan cat pada dinding. }\end{array}$ & $\begin{array}{l}\text { Dinding pos bank sampah ini masih } \\
\text { berdiri dengan cukup baik namun ada } \\
\text { beberapa bagian yang mengalami } \\
\text { kerusakan akibat pelapukan oleh air. }\end{array}$ \\
\hline
\end{tabular}


Planners InSight Vol. 2 No No. 2, Agustus 2019 | ISSN 2615 - 7055

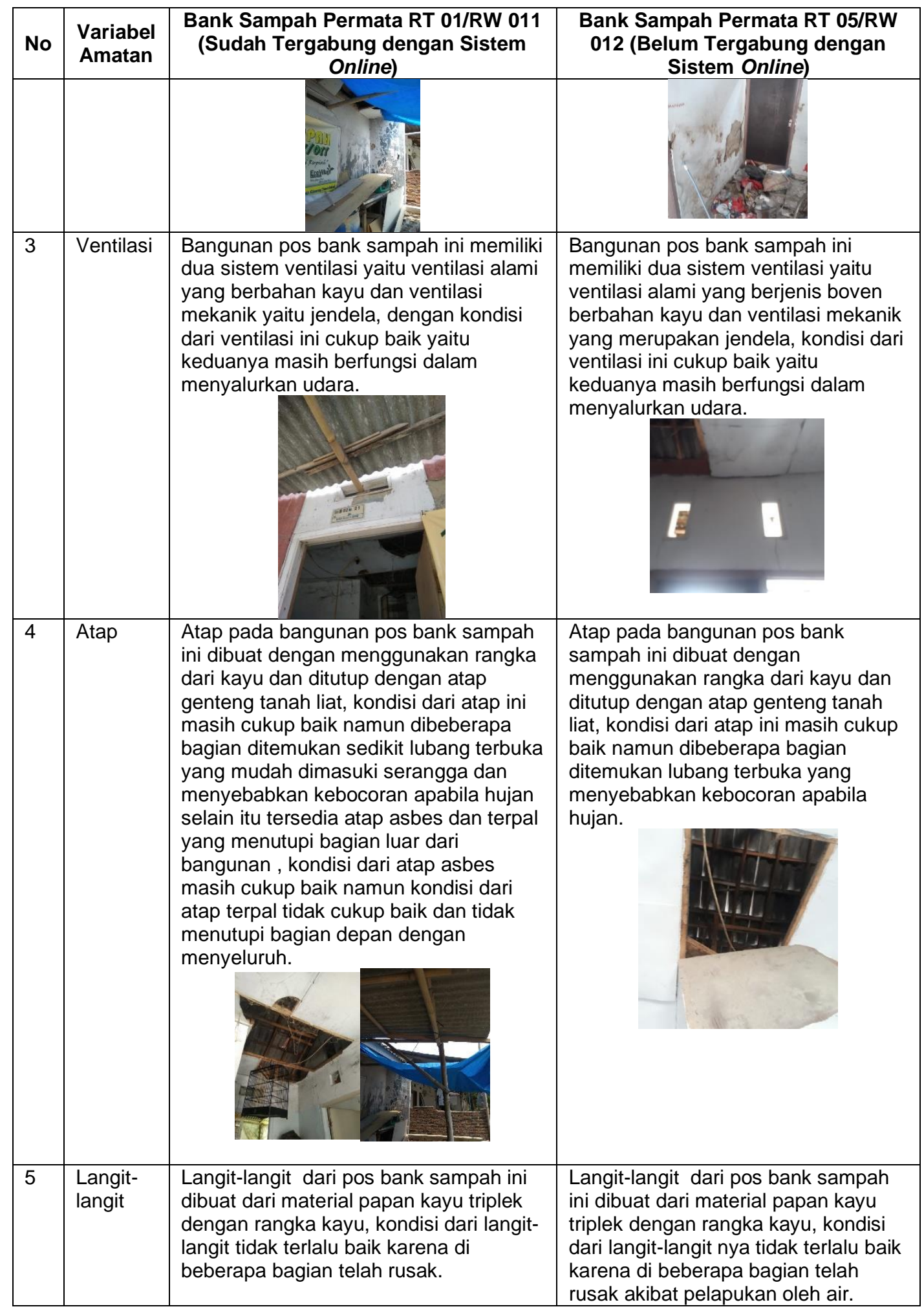




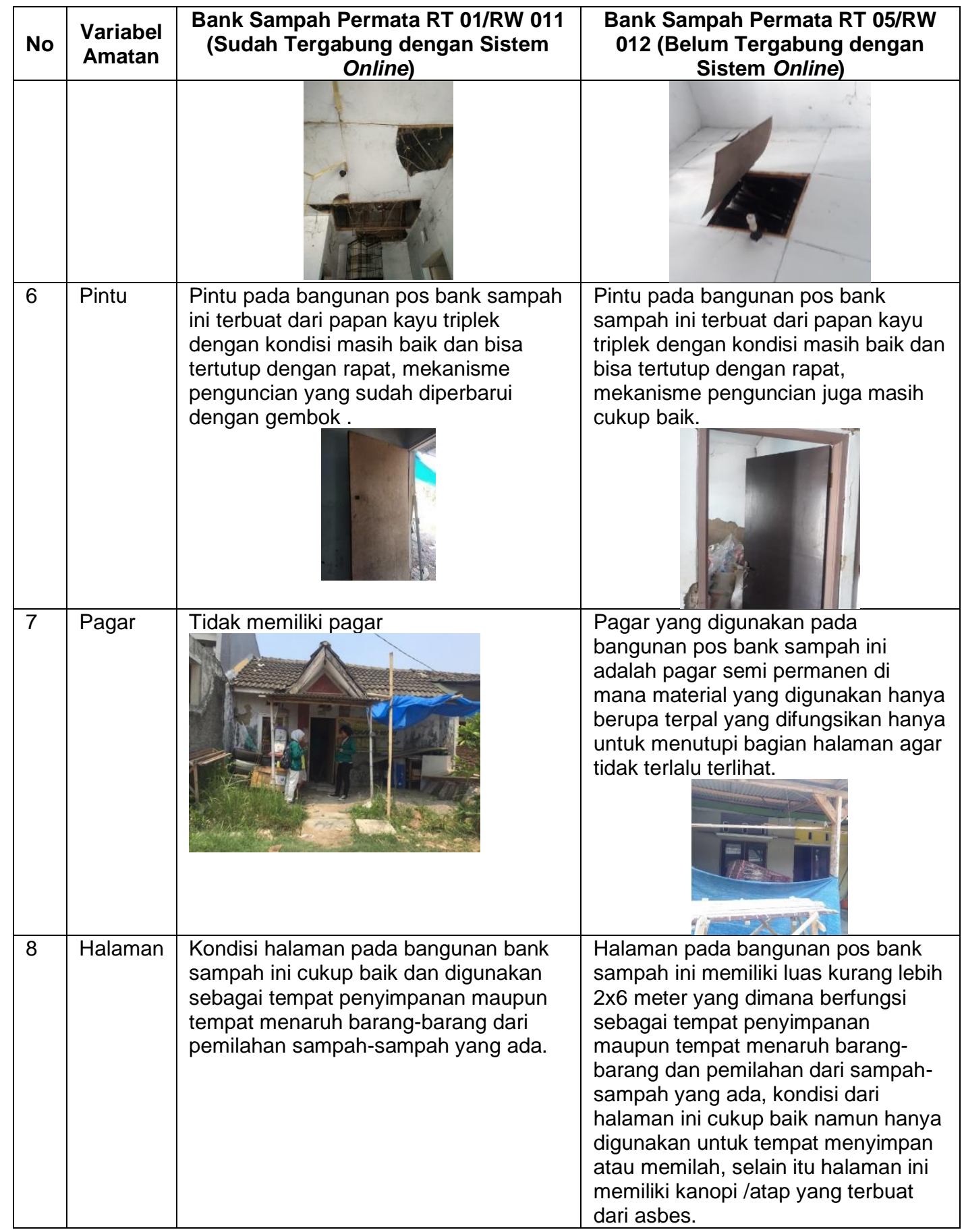




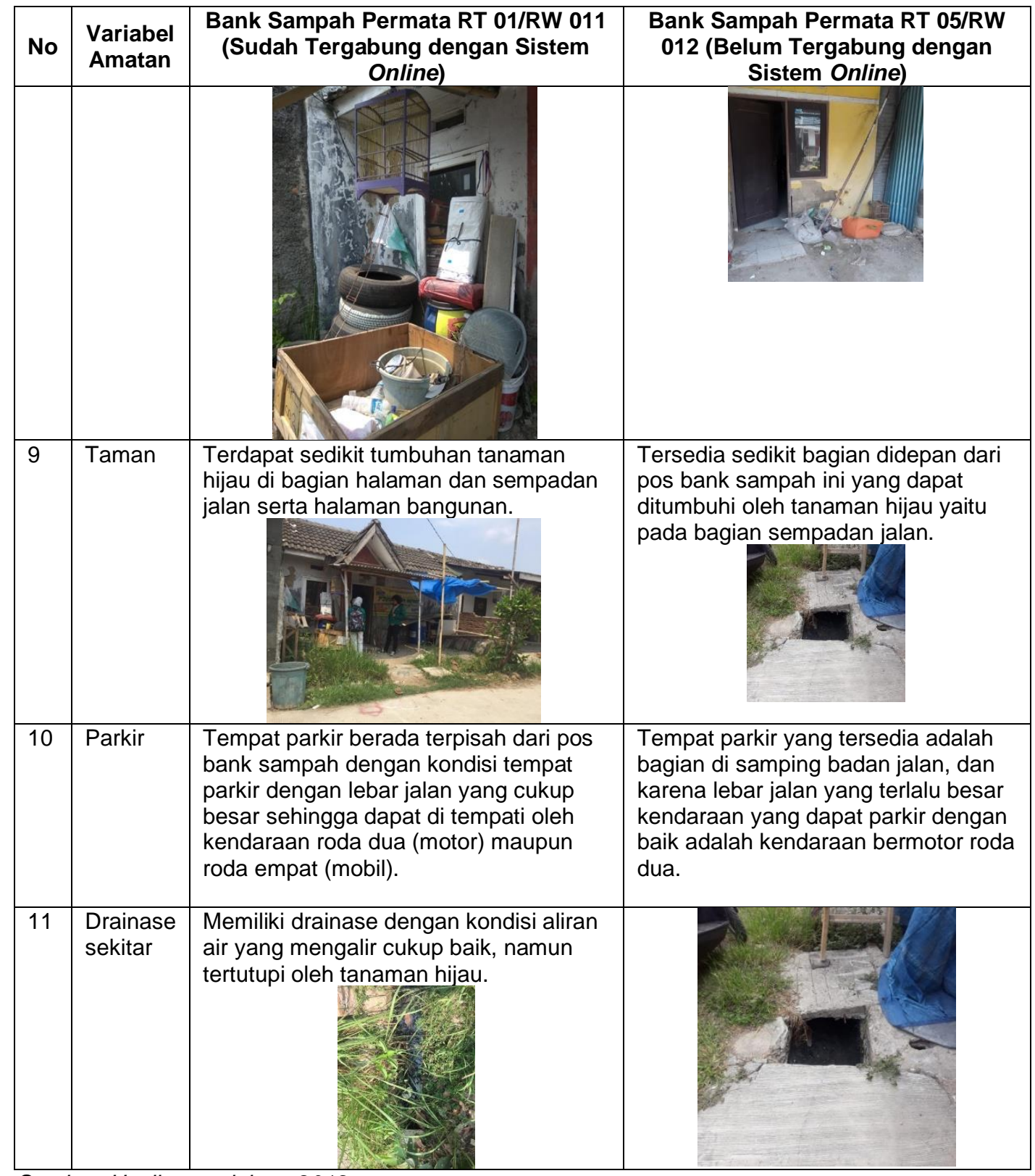

Sumber: Hasil pengolahan, 2019

\section{b. Ruang Pelayanan Bank Sampah}

Secara fisik, kondisi ruang pelayanan bank sampah yang sudah dan belum tergabung dengan sistem online tidak memiliki perbedaan yang cukup signifikan baik dari kondisi ruang pemilahan sampah, fasilitas: meja, kursi, timbangan, lemari, alat pemadam api ringan, dll, instrumen bank sampah, bau, kebersihan, pencahayaan dan suhu ruangan. 
Tabel 2 Perbandingan Sistem Pembelian Sampah

\begin{tabular}{|c|c|c|c|}
\hline No & $\begin{array}{l}\text { Variabel } \\
\text { Amatan }\end{array}$ & $\begin{array}{c}\text { Bank Sampah Permata RT 01/RW } \\
011 \text { (Sudah Tergabung dengan } \\
\text { Sistem Online) }\end{array}$ & $\begin{array}{c}\text { Bank Sampah Permata RT 05/RW } \\
012 \text { (Belum Tergabung dengan } \\
\text { Sistem Online) }\end{array}$ \\
\hline 1 & $\begin{array}{l}\text { Nasabah bank } \\
\text { sampah }\end{array}$ & $\begin{array}{l}\text { Semua warga di dalam RT } 01 \mathrm{RW} \\
011 \text { dan dari luar lingkungan RT } \\
\text { tersebut. Semua aktif menjadi } \\
\text { nasabah bank sampah dan } \\
\text { penarikan dilakukan setiap dua } \\
\text { minggu sekali. }\end{array}$ & $\begin{array}{l}\text { Warga yang hanya berasal dari } \\
\text { wilayah RT05/RW012. }\end{array}$ \\
\hline 2 & $\begin{array}{l}\text { Cakupan } \\
\text { pelayanan }\end{array}$ & $\begin{array}{l}\text { Lingkup wilayah pelayanan adalah } \\
\text { seluruh wilayah RT } 01 \text { dan } \\
\text { beberapa rumah dari RT lainya } \\
\text { yang merupakan nasabah dari bank } \\
\text { sampah (tetap di dalam RW yang } \\
\text { sama), jumlah nasabah +/- } 40 \mathrm{KK} \\
\text { dari RT } 01 \text { dan +/- } 10 \mathrm{KK} \text { dari luar } \\
\text { RT } 01 \text {. }\end{array}$ & $\begin{array}{l}\text { Cakupan pelayanan bank sampah } \\
\text { sejauh ini hanya masih melayani } \\
\text { wilayah dari RT05/RW012 saja } \\
\text { dengan jumlah nasabah sebanyak } \\
60 \text { KK yang semuanya berasal dari } \\
\text { RT tersebut. }\end{array}$ \\
\hline 3 & $\begin{array}{l}\text { Penyuluhan } \\
\text { terkait bank } \\
\text { sampah }\end{array}$ & $\begin{array}{l}\text { Ada penyuluhan terkait bank } \\
\text { sampah yang dilakukan dari pihak } \\
\text { Dinas Lingkungan Hidup Kabupaten } \\
\text { Bekasi melalui komunitas/lembaga } \\
\text { pemerhati lingkungan bernama } \\
\text { Jangkar dengan program nya } \\
\text { berupa Eco Village, di mana } \\
\text { sosialisasi ini diarahkan kepada } \\
\text { para pengurus RT di perumahan } \\
\text { Permata Cikarang Timur, } \\
\text { selanjutnya dari sosialisasi tersebut } \\
\text { hanya ada empat RT yang tertarik } \\
\text { dan bersedia untuk menjalankan } \\
\text { program ini khususnya pada bank } \\
\text { sampah, yang termasuk RT 01 RW } \\
\text { 11, setelah itu pihak RT melalui } \\
\text { kepanitiaan program bank sampah } \\
\text { melakukan penyuluhan dan diskusi } \\
\text { dengan para warganya dengan } \\
\text { output berupa mengajak mereka } \\
\text { untuk menjadi nasabah bank } \\
\text { sampah. }\end{array}$ & $\begin{array}{l}\text { Sebelum diadakanya bank sampah } \\
\text { warga terlebih dahulu dikumpulkan } \\
\text { di tempat fasilitas sosial RT dan } \\
\text { diadakan sosialisasi tentang bank } \\
\text { sampah mulai dari tujuan, manfaat } \\
\text { jangka pendek, jangka menengah, } \\
\text { dan jangka panjang mengenai bank } \\
\text { sampah. }\end{array}$ \\
\hline 4 & $\begin{array}{l}\text { Pemberian } \\
\text { wadah } \\
\text { sampah } \\
\text { terpilah }\end{array}$ & $\begin{array}{l}\text { Nasabah tidak diberikan fasilitas } \\
\text { pemilah sampah yang ditempatkan } \\
\text { perumah, namun tersedia tempat } \\
\text { sampah komunal yang sudah } \\
\text { dibedakan berdasarkan jenis } \\
\text { sampahnya. }\end{array}$ & $\begin{array}{l}\text { Untuk wadah nasabah masih } \\
\text { menggunakan karung dan setiap } \\
\text { nasabah yang ingin menyetorkan } \\
\text { sampahnya bisa langsung } \\
\text { disetorkan ke tempat bank sampah } \\
\text { untuk ditukarkan dan karung yang } \\
\text { digunakan dikembalikan lagi ke } \\
\text { nasabah untuk menyetorkan } \\
\text { sampah di kemudian hari. }\end{array}$ \\
\hline 5 & $\begin{array}{l}\text { Sistem } \\
\text { pemilahan } \\
\text { sampah }\end{array}$ & $\begin{array}{l}\text { Untuk memilah sampah mereka } \\
\text { diberikan arahan untuk dapat } \\
\text { memisahkan sampah organik dan } \\
\text { anorganik yang berasal dari limbah } \\
\text { domestik (sampah rumah tangga), } \\
\text { di mana ada beberapa jenis } \\
\text { sampah yang memiliki nilai }\end{array}$ & $\begin{array}{l}\text { Untuk pemilahan sampah, nasabah } \\
\text { sudah melakukan pemilahan } \\
\text { sampah di rumah masing-masing } \\
\text { sebelum sampah di setorkan ke } \\
\text { bank sampah, seperti sampah } \\
\text { organik dan anorganik yang berasal } \\
\text { dari limbah domestik (sampah }\end{array}$ \\
\hline
\end{tabular}


Planners InSight Vol. 2 No. No. 2, Agustus 2019 | ISSN 2615 - 7055

\begin{tabular}{|c|c|c|c|}
\hline No & $\begin{array}{l}\text { Variabel } \\
\text { Amatan }\end{array}$ & $\begin{array}{c}\text { Bank Sampah Permata RT 01/RW } \\
011 \text { (Sudah Tergabung dengan } \\
\text { Sistem Online) }\end{array}$ & $\begin{array}{c}\text { Bank Sampah Permata RT 05/RW } \\
012 \text { (Belum Tergabung dengan } \\
\text { Sistem Online) }\end{array}$ \\
\hline & & $\begin{array}{l}\text { ekonomis dan akan dikumpulkan } \\
\text { untuk di tabung dibank sampah. } \\
\text { Sampah yang telah dipilah bisa } \\
\text { disetorkan ke bank sampah dengan } \\
\text { cara diantar langsung oleh nasabah } \\
\text { atau dengan cara dijemput oleh } \\
\text { bank sampah tersebut. Untuk } \\
\text { penarikan dari bank sampah } \\
\text { dilakukan setiap dua minggu sekali. }\end{array}$ & $\begin{array}{l}\text { rumah tangga), di mana terdapat } \\
\text { beberapa jenis sampah yang } \\
\text { memiliki nilai ekonomis dan akan } \\
\text { dikumpulkan untuk di tabung di } \\
\text { bank sampah. Dinas Lingkungan } \\
\text { Hidup memberikan fasilitas tempat } \\
\text { sampah sesuai dengan jenisnya, } \\
\text { yaitu tempat sampah organik, } \\
\text { anorganik, B3 yang terletak hanya } \\
\text { di fasilitas sosial RT saja. }\end{array}$ \\
\hline 6 & $\begin{array}{l}\text { Upaya } \\
\text { mengurangi } \\
\text { sampah }\end{array}$ & $\begin{array}{l}\text { Nasabah bank sampah melakukan } \\
\text { upaya mengurangi sampah dengan } \\
\text { cara membedakan jenis sampah, } \\
\text { seperti sampah dapur atau sampah } \\
\text { sisa makanan dan sampah plastic, } \\
\text { kaca, atau kardus. Untuk sampah } \\
\text { dapur atau sampah sisa makanan } \\
\text { disetorkan ke truk pengangkut } \\
\text { sampah yang dilakukan lima kali } \\
\text { pengangkutan dalam } 1 \text { bulan. }\end{array}$ & $\begin{array}{l}\text { Dalam hal upaya mengurangi } \\
\text { sampah masih relatif, tetapi } \\
\text { sekarang mulai berkurang sampah- } \\
\text { sampah dari warung-warung milik } \\
\text { warga. }\end{array}$ \\
\hline 7 & $\begin{array}{l}\text { Buku } \\
\text { tabungan dan } \\
\text { nomor } \\
\text { rekening } \\
\text { sampah }\end{array}$ & $\begin{array}{l}\text { Masyarakat yang menjadi nasabah } \\
\text { bank sampah diberikan rekening } \\
\text { dalam bentuk buku tabungan bank } \\
\text { sampah namun belum memiliki } \\
\text { nomor rekening yang terkoneksi } \\
\text { dengan lembaga keuangan/bank } \\
\text { konvensional dimana pengelolaan } \\
\text { uangnya masih diurus secara } \\
\text { swadaya oleh masyarakat. }\end{array}$ & $\begin{array}{l}\text { Untuk nasabah masing-masing } \\
\text { memiliki buku tabungan dan ada } \\
\text { juga pembukuannya yang dipegang } \\
\text { langsung oleh pengelola. } \\
\text { Masyarakat yang menjadi nasabah } \\
\text { bank sampah diberikan rekening } \\
\text { dalam bentuk buku tabungan bank } \\
\text { sampah namun belum memiliki } \\
\text { nomor rekening yang terkoneksi } \\
\text { dengan lembaga keuangan/bank } \\
\text { konvensional dimana pengelolaan } \\
\text { uangnya masih diurus secara } \\
\text { swadaya oleh masyarakat. }\end{array}$ \\
\hline 8 & $\begin{array}{l}\text { Mekanisme } \\
\text { pencatatan } \\
\text { tabungan } \\
\text { sampah }\end{array}$ & $\begin{array}{l}\text { Pencatatan/pembukuan dari hasil } \\
\text { bank sampah dikelola oleh } \\
\text { pengurus bank sampah dan direkap } \\
\text { selama dua minggu sekali, } \\
\text { berdasarkan mekanisme nya } \\
\text { diketahui bahwa: } \\
\text { 1. Nasabah bank sampah } \\
\text { menyetorkan sampah yang } \\
\text { telah dipilah berdasarkan } \\
\text { jenisnya (sampah yang dibeli } \\
\text { adalah sampah kering) kepada } \\
\text { pengurus bank sampah. } \\
\text { 2. Pengurus akan menimbang } \\
\text { sampah yang telah disetorkan } \\
\text { dan akan menghitung serta } \\
\text { menilai total harga sampah } \\
\text { berdasarkan jenis dan kondisi } \\
\text { nya. } \\
\text { Setelah ditentukan nilai } \\
\text { sampah nya pengurus akan } \\
\text { menulis total penyetoran } \\
\text { sampah (harga, berat, jenis, }\end{array}$ & $\begin{array}{l}\text { Di RT } 05 \text { bank sampah tersebut } \\
\text { sudah memiliki seperti buku kas, } \\
\text { buku penjualan, buku tabungan } \\
\text { yang dikelola oleh anggota } \\
\text { pengelola bank sampah. }\end{array}$ \\
\hline
\end{tabular}


Planners InSight Vol. 2 No. 2, Agustus 2019 | ISSN 2615 - 7055

\begin{tabular}{|c|c|c|c|}
\hline No & $\begin{array}{l}\text { Variabel } \\
\text { Amatan }\end{array}$ & $\begin{array}{c}\text { Bank Sampah Permata RT 01/RW } \\
011 \text { (Sudah Tergabung dengan } \\
\text { Sistem Online) }\end{array}$ & $\begin{array}{c}\text { Bank Sampah Permata RT 05/RW } \\
012 \text { (Belum Tergabung dengan } \\
\text { Sistem Online) }\end{array}$ \\
\hline & & $\begin{array}{l}\text { kondisi dan tanggal } \\
\text { penyotoran) nasabah kedalam } \\
\text { buku besar dan buku tabungan } \\
\text { nasabah. }\end{array}$ & \\
\hline 9 & $\begin{array}{l}\text { Mekanisme } \\
\text { penarikan } \\
\text { tabungan } \\
\text { sampah }\end{array}$ & $\begin{array}{l}\text { Mekanisme penarikan keuntungan } \\
\text { nasabah bank sampah antara lain: } \\
\text { a. Penjualan seluruh tabungan } \\
\text { sampah yang disetorkan oleh } \\
\text { nasabah dilakukan setiap dua } \\
\text { minggu sekali. } \\
\text { b. Sampah tersebut dijual kepada } \\
\text { pengepul bank sampah. } \\
\text { c. Uang hasil dari pemasukan } \\
\text { bank sampah tersebut } \\
\text { disisihkan terlebih dahulu oleh } \\
\text { pengurus untuk biaya } \\
\text { operasional bank sampah } \\
\text { sesuai dengan kesepakatan } \\
\text { bersama. } \\
\text { Uang yang dimiliki oleh } \\
\text { nasabah dari hasil penjualan } \\
\text { sampah dapat diambil secara } \\
\text { langsung ataupun dapat } \\
\text { ditabungkan didalam rekening } \\
\text { nasabah melalui buku } \\
\text { tabungan. }\end{array}$ & $\begin{array}{l}\text { Untuk penarikan tabungan bank } \\
\text { sampah, nasabah dapat mengambil } \\
\text { uang hasil penukaran kapan saja } \\
\text { bila membutuhkan. }\end{array}$ \\
\hline 10 & $\begin{array}{l}\text { Peminjaman } \\
\text { uang }\end{array}$ & $\begin{array}{l}\text { Nasabah bank sampah dapat } \\
\text { meminjam uang ke bank sampah. } \\
\text { Nasabah juga bisa langsung } \\
\text { mengambil uang hasil dari } \\
\text { penukaran sampah. }\end{array}$ & $\begin{array}{l}\text { Belum ada, untuk saat ini masih } \\
\text { dengan cara menabung saja lewat } \\
\text { bank sampah. }\end{array}$ \\
\hline 11 & $\begin{array}{l}\text { Jasa } \\
\text { penjemputan } \\
\text { sampah }\end{array}$ & $\begin{array}{l}\text { Pada bank sampah ini terdapat jasa } \\
\text { penjemputan sampah, yang } \\
\text { dilakukan setiap dua minggu sekali } \\
\text { oleh pengurus bank sampah } \\
\text { dengan menggunakan gerobak } \\
\text { yang biasa digunakan untuk kerja } \\
\text { bakti, karena bank sampah tersebut } \\
\text { belum mempunyai gerobak yang } \\
\text { standar untuk pengangkutan } \\
\text { sampah. Penjemputan ini dilakukan } \\
\text { dengan berkeliling RT } 01 \text { dari pintu } \\
\text { kepintu, namun apabila nasabah } \\
\text { tidak sempat menggunakan jasa } \\
\text { penjemputan, nasabah dapat } \\
\text { menyetorkan langsung sampahnya } \\
\text { kepada pengurus di pos bank } \\
\text { sampah. }\end{array}$ & $\begin{array}{l}\text { Pada bank sampah ini terdapat jasa } \\
\text { penjemputan sampah, yang } \\
\text { dilakukan oleh pengurus bank } \\
\text { sampah dengan menggunakan } \\
\text { gerobak. Penjemputan ini dilakukan } \\
\text { dengan berkeliling RT } 05 \text { dari pintu } \\
\text { kepintu, namun apabila nasabah } \\
\text { tidak sempat menggunakan jasa } \\
\text { penjemputan, nasabah dapat } \\
\text { menyetorkan langsung sampahnya } \\
\text { kepada pengurus di pos bank } \\
\text { sampah. }\end{array}$ \\
\hline 12 & $\begin{array}{l}\text { Jenis dan } \\
\text { kondisi } \\
\text { sampah yang } \\
\text { diterima }\end{array}$ & $\begin{array}{l}\text { Jenis sampah yang dapat diterima } \\
\text { oleh bank sampah yaitu sampah } \\
\text { anorganik seperti, kaleng, beling, } \\
\text { kardus, botol minuman plastic dan } \\
\text { perabotan rumah tangga bekas }\end{array}$ & $\begin{array}{l}\text { Jenis sampah yang dapat diterima } \\
\text { oleh bank sampah yaitu sampah } \\
\text { anorganik seperti, kaleng, beling, } \\
\text { kardus, botol minuman plastic dan } \\
\text { perabotan rumah tangga bekas. }\end{array}$ \\
\hline
\end{tabular}


Planners InSight Vol. 2 No. No. 2, Agustus 2019 | ISSN 2615 - 7055

\begin{tabular}{|c|c|c|c|}
\hline No & $\begin{array}{l}\text { Variabel } \\
\text { Amatan }\end{array}$ & $\begin{array}{c}\text { Bank Sampah Permata RT 01/RW } \\
011 \text { (Sudah Tergabung dengan } \\
\text { Sistem Online) }\end{array}$ & $\begin{array}{c}\text { Bank Sampah Permata RT 05/RW } \\
012 \text { (Belum Tergabung dengan } \\
\text { Sistem Online) }\end{array}$ \\
\hline & & $\begin{array}{l}\text { kecuali sampah dapur atau sampah } \\
\text { sisa makanan tidak diterima di bank } \\
\text { sampah tersebut. Sampah yang } \\
\text { disetorkan ke bank sampah } \\
\text { diharapkan memiliki kondisi yang } \\
\text { cukup baik contoh nya; botol kaca } \\
\text { masih utuh dan tidak pecah, } \\
\text { sampah kardus masih dalam } \\
\text { kondisi kering dan tidak basah atau } \\
\text { terlerai. }\end{array}$ & $\begin{array}{l}\text { Botol plastik memiliki harga yang } \\
\text { berbeda dari segi tutup botol yang } \\
\text { sudah dipisahkan dan label yang } \\
\text { terdapat di botol dan mempunyai } \\
\text { harga lebih tinggi. Sampah yang } \\
\text { disetorkan ke bank sampah } \\
\text { diharapkan memiliki kondisi yang } \\
\text { cukup baik contoh nya; botol kaca } \\
\text { masih utuh dan tidak pecah, } \\
\text { sampah kardus masih dalam } \\
\text { kondisi kering dan tidak basah atau } \\
\text { terlerai. }\end{array}$ \\
\hline 13 & $\begin{array}{l}\text { Harga beli } \\
\text { sampah }\end{array}$ & $\begin{array}{l}\text { Harga beli sampah yang diterima } \\
\text { dari penabung/ nasabah bank } \\
\text { sampah sangat relatif, tergantung } \\
\text { dengan jenis sampahnya seperi } \\
\text { kaleng dijual dengan harga Rp. } \\
1.000 / \mathrm{kg} \text {, kardus Rp. } 1.300 / \mathrm{kg}, \\
\text { botol plastic/aqua Rp. } 3.000 / \mathrm{kg} \text {. } \\
\text { Sampah botol plastik yang } \\
\text { disetorkan juga harus udah bersih } \\
\text { dan telah dicuci lalu dipisahkan } \\
\text { antara tutup dan botolnya serta } \\
\text { label telah dilepaskan. }\end{array}$ & $\begin{array}{l}\text { Harga beli sampah yang diterima } \\
\text { dari penabung/ nasabah bank } \\
\text { sampah sangat relatif, tergantung } \\
\text { dengan jenis sampahnya seperi } \\
\text { kaleng dijual dengan harga Rp. } \\
1000 / \mathrm{kg} \text {, kardus } \mathrm{Rp} .1 .300 / \mathrm{kg} \text {, botol } \\
\text { plastic/aqua Rp. } 3.000 / \mathrm{kg} \text {. harga } \\
\text { beli ini merupakan diambil dengan } \\
\text { kondisi terbaik }\end{array}$ \\
\hline 14 & $\begin{array}{l}\text { Minimm } \\
\text { jumlah setor } \\
\text { sampah }\end{array}$ & $\begin{array}{l}\text { Untuk berat minimum tergantung } \\
\text { dari penyetoran nasabah ke bank } \\
\text { sampah dan tidak ada batasan } \\
\text { berat untuk penyetoran sampah. }\end{array}$ & $\begin{array}{l}\text { Untuk berat minimum tergantung } \\
\text { dari penyetoran nasabah bank } \\
\text { sampah ke bank sampah dan tidak } \\
\text { ada batasan untuk penyetoran } \\
\text { sampah dengan wadah yang sudah } \\
\text { tersedia. }\end{array}$ \\
\hline
\end{tabular}

Sumber: Hasil pengolahan, 2019

\section{c. Sistem Pembelian Sampah}

Dalam sistem pembelian sampah, tidak terdapat perbedaan yang mencolok antara sistem pembelian sampah yang diterapkan oleh bank sampah yang sudah dan belum tergabung dengan sistem online. Perbedaan hanya terdapat pada 1 variabel amatan, yaitu terkait dengan peminjaman uang. Pada bank sampah yang telah terdaftar dengan sistem online di Smash, nasabah bank sampah dapat meminjam uang ke bank sampah. Nasabah juga bisa langsung mengambil uang hasil dari penukaran sampah. Sedangkan pada bank sampah yang belum bergabung dengan sistem online, belum ada sistem peminjaman uang, hanya mekanisme menabung saja.

Tabel 3 Perbandingan Ruang Pelayanan Bank Sampah

\begin{tabular}{|l|l|l|l|}
\hline No & \multicolumn{1}{|l|}{$\begin{array}{l}\text { Variabel } \\
\text { Amatan }\end{array}$} & $\begin{array}{l}\text { Bank Sampah Permata RT 01/RW } \\
\mathbf{0 1 1} \text { (Sudah Tergabung dengan } \\
\text { Sistem Online) }\end{array}$ & $\begin{array}{c}\text { Bank Sampah Permata RT 05/RW } \\
\mathbf{0 1 2} \text { (Belum Tergabung dengan } \\
\text { Sistem Online) }\end{array}$ \\
\hline 1 & $\begin{array}{l}\text { Ruang } \\
\text { pemilahan } \\
\text { sampah }\end{array}$ & $\begin{array}{l}\text { Memiliki ruang pemilahan sampah } \\
\text { yang berada di halaman dan bagian } \\
\text { dalam bangunan yang dijadikan } \\
\text { sebagai gudang/tempat } \\
\text { penyimpanan barang. }\end{array}$ & $\begin{array}{l}\text { Pada pos bank sampah ini ruangan } \\
\text { yang digunakan sebagai tempat } \\
\text { pemilahan sampah adalah halaman } \\
\text { dan salah satu kamar di dalam } \\
\text { bangunan digunakan sebagai } \\
\text { gudang, pada bagian halaman } \\
\text { sampah yang telah dikumpulkan oleh } \\
\text { gerobak. }\end{array}$ \\
\hline & &
\end{tabular}




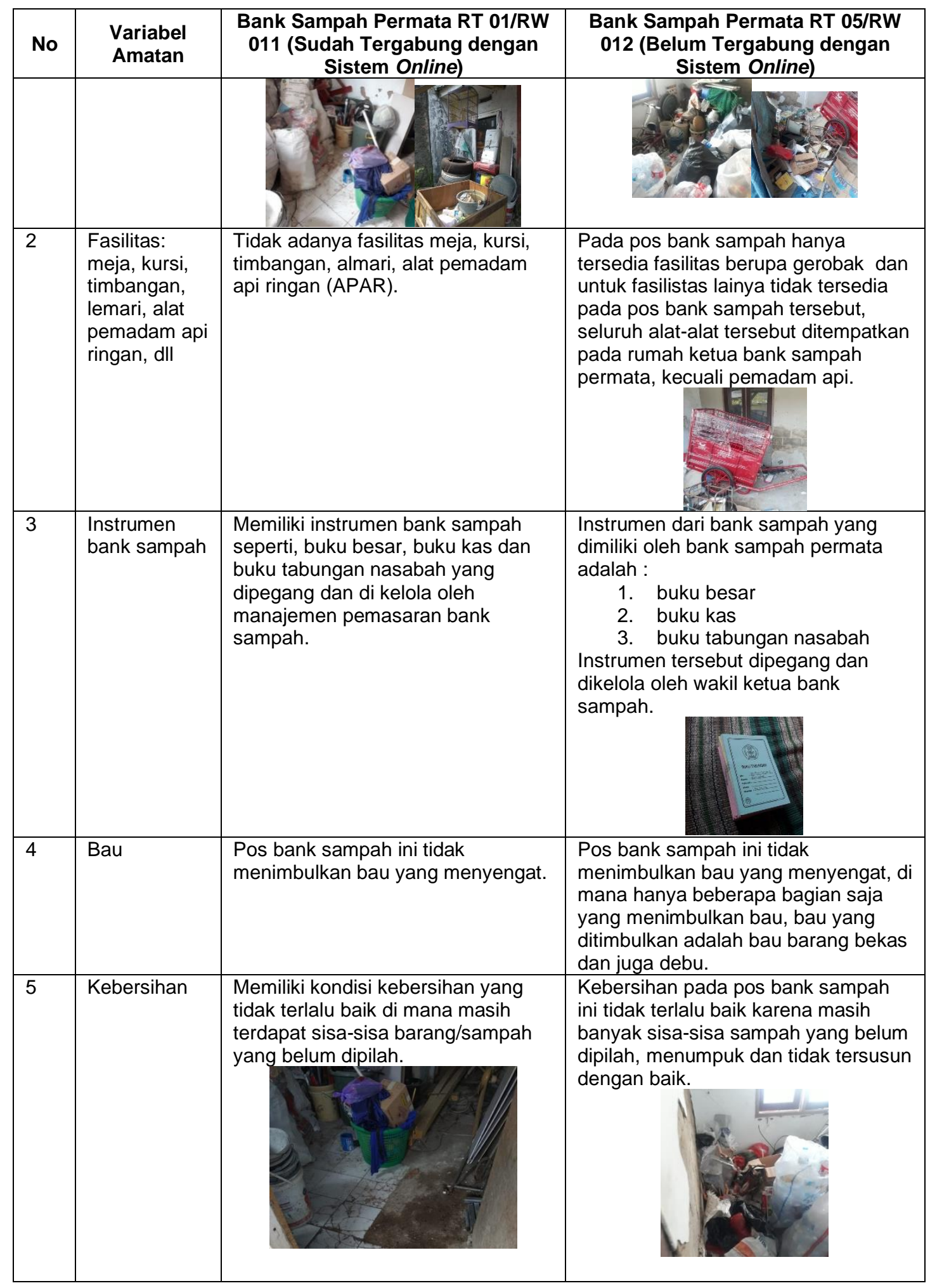


Planners InSight Vol. 2 No. No. 2, Agustus 2019 | ISSN 2615 - 7055

\begin{tabular}{|c|c|c|c|}
\hline No & $\begin{array}{l}\text { Variabel } \\
\text { Amatan }\end{array}$ & $\begin{array}{c}\text { Bank Sampah Permata RT 01/RW } \\
011 \text { (Sudah Tergabung dengan } \\
\text { Sistem Online) }\end{array}$ & $\begin{array}{c}\text { Bank Sampah Permata RT 05/RW } \\
012 \text { (Belum Tergabung dengan } \\
\text { Sistem Online) }\end{array}$ \\
\hline 6 & Pencahayaan & $\begin{array}{l}\text { Pada bangunan pos bank sampah } \\
\text { ini memiliki dua sistem } \\
\text { pencahayaan di mana sistem } \\
\text { pencahayaan alami dan buatan, } \\
\text { dengan kondisi yaitu: } \\
\text { a. memiliki sistem pencahayaan } \\
\text { alami sehingga bagian dalam } \\
\text { bangunan mendapat } \\
\text { pencahayaan yang cukup baik } \\
\text { di siang hari. } \\
\text { b. tidak memiliki sistem } \\
\text { pencahayaan buatan sehingga } \\
\text { tidak mendapat pencahayaan } \\
\text { yang baik di malam hari. }\end{array}$ & $\begin{array}{l}\text { Pada bangunan pos bank sampah ini } \\
\text { memiliki dua sistem pencahayaan di } \\
\text { mana sistem pencahayaan alami dan } \\
\text { buatan, dengan kondisi yaitu: } \\
\text { a. } \quad \text { sistem pencahayaan alami } \\
\text { dinyatakan baik karena ruangan } \\
\text { bagian dalam dari bangunan } \\
\text { mendapat pencahayaan yang } \\
\text { cukup pada siang hari } \\
\text { b. sistem pencahayaan buatan } \\
\text { dinyatakan tidak baik karena } \\
\text { pada pos bank sampah ini tidak } \\
\text { teraliri listrik dan sistem } \\
\text { pencahayaan buatan pun tidak } \\
\text { dapat menyala }\end{array}$ \\
\hline 7 & $\begin{array}{l}\text { Suhu } \\
\text { ruangan }\end{array}$ & $\begin{array}{l}\text { Pada saat observasi dilakukan } \\
\text { (pukul 13:45) tercatat bahwa suhu } \\
\text { ruangan dari pos bank sampah } \\
\text { adalah } 26 \text { derajat celcius dengan } \\
\text { suhu luar ruangan } 33 \text { derajat } \\
\text { celcius. }\end{array}$ & $\begin{array}{l}\text { Pada saat observasi dilakukan (pukul } \\
14: 24 \text { ) tercatat bahwa suhu ruangan } \\
\text { dari pos bank sampah adalah } 27 \\
\text { derajat celcius dengan suhu luar } \\
\text { ruangan } 33 \text { derajat celcius. }\end{array}$ \\
\hline
\end{tabular}

Sumber: Hasil pengolahan, 2019

\section{d. Sistem Penjualan Sampah}

Dalam sistem penjualan sampah, tidak terdapat perbedaan yang mencolok antara sistem pembelian sampah yang diterapkan oleh bank sampah yang sudah dan belum tergabung dengan sistem online. Perbedaan hanya terdapat pada 2 variabel amatan, yaitu terkait dengan partisipasi dalam sistem online (Smash) yang berdampak pada semakin dikenalnya bank sampah jika sudah tergabung dengan sistem online. Dengan semakin dikenalnya suatu bank sampah, maka terdapat beberapa keuntungan diantaranya:

- menghubungkan dan mendekatkan supply dan demand yaitu antara nasabah, bank sampah dan konsumen/pelanggan sampah; dan

- perolehan dana hibah dan CSR yang lebih prospektif untuk bank sampah yang sudah bergabung dengan sistem online (Smah).

Kendala yang ditemukan bagi bank sampah yang telah tergabung dengan sistem online Smash adalah lupa password dan kurang paham terkait skema dan sistem. Sedangkan alasan bank sampah yang belum bergabung dengan sistem online Smash adalah kesulitan dalam memenuhi persyaratan/birokrasi yang ditetapkan oleh Smash.

Tabel 4 Perbandingan Sistem Penjualan Sampah

\begin{tabular}{|c|c|c|c|}
\hline No & $\begin{array}{c}\text { Variabel } \\
\text { Amatan }\end{array}$ & $\begin{array}{c}\text { Bank Sampah Permata RT } \\
\text { 01/RW 011 (Sudah Tergabung } \\
\text { dengan Sistem Online) }\end{array}$ & $\begin{array}{c}\text { Bank Sampah Permata RT 05/RW } \\
\mathbf{0 1 2} \text { (Belum Tergabung dengan } \\
\text { Sistem Online) }\end{array}$ \\
\hline 1 & Pembeli sampah & $\begin{array}{l}\text { Setelah sampah yang terkumpul } \\
\text { di bank sampah pengurus bank } \\
\text { sampah menyetorkan sampah- } \\
\text { sampah tersebut ke pengepul }\end{array}$ & $\begin{array}{l}\text { Setelah sampah yang terkumpul di } \\
\text { bank sampah pengurus bank sampah } \\
\text { menyetorkan sampah-sampah } \\
\text { tersebut ke pengepul atau tengkulak. }\end{array}$ \\
\hline
\end{tabular}




\begin{tabular}{|c|c|c|c|}
\hline No & $\begin{array}{l}\text { Variabel } \\
\text { Amatan }\end{array}$ & $\begin{array}{c}\text { Bank Sampah Permata RT } \\
\text { 01/RW } 011 \text { (Sudah Tergabung } \\
\text { dengan Sistem Online) }\end{array}$ & $\begin{array}{c}\text { Bank Sampah Permata RT 05/RW } \\
012 \text { (Belum Tergabung dengan } \\
\text { Sistem Online) }\end{array}$ \\
\hline & & $\begin{array}{l}\text { atau tengkulak. Pengepul tersebut } \\
\text { bertempat disekitar desa Jatireja, } \\
\text { Cikarang Timur. Untuk } \\
\text { pengangkutannya sendiri } \\
\text { dilakukan dengan cara dijemput } \\
\text { oleh pengepul ke tempat bank } \\
\text { sampah dan sudah ditimbang oleh } \\
\text { pengurus bank sampah lalu } \\
\text { sampah tersebut dibeli dan } \\
\text { diangkut oleh pengepul. }\end{array}$ & $\begin{array}{l}\text { Pengepul tersebut bertempat disekitar } \\
\text { desa Jatireja, Cikarang Timur. Untuk } \\
\text { pengangkutannya sendiri dilakukan } \\
\text { dengan cara dijemput oleh pengepul } \\
\text { ke tempat bank sampah dan sudah } \\
\text { ditimbang oleh pengurus bank } \\
\text { sampah lalu sampah tersebut dibeli } \\
\text { dan diangkut oleh pengepul. } \\
\text { Sedangkan untuk bank sampah induk } \\
\text { yang dapat menampung sampah dari } \\
\text { bank sampah unit tidak tersedia } \\
\text { dalam lingkup desa, sehingga } \\
\text { pengumpulan sampah hanya } \\
\text { terhubung dengan pengepul saja }\end{array}$ \\
\hline 2 & $\begin{array}{l}\text { Harga jual } \\
\text { sampah }\end{array}$ & $\begin{array}{l}\text { Harga jual yang dibeli oleh } \\
\text { pengepul tidak jauh berbeda } \\
\text { dengan harga beli sampah yang } \\
\text { diterima dari nasabah bank, } \\
\text { misalnya harga yang di beli oleh } \\
\text { bank sampah dari nasabah bank } \\
\text { Rp. } 3.000 / \mathrm{kg} \text {, maka harga jual ke } \\
\text { pengepul dijual dengan harga Rp. } \\
\text { 4.000/kg. Selisih Rp. } 1.000 \\
\text { digunakan oleh pengurus bank } \\
\text { sampah untuk membeli minuman } \\
\text { bagi para pekerja. }\end{array}$ & $\begin{array}{l}\text { Harga jual yang dibeli oleh pengepul } \\
\text { tidak jauh berbeda dengan harga beli } \\
\text { sampah yang diterima dengan } \\
\text { memiliki selisih yang lebih sedikit dari } \\
\text { nasabah bank, misalnya harga yang } \\
\text { di beli oleh bank sampah dari } \\
\text { nasabah bank Rp. } 3.000 / \mathrm{kg} \text {, maka } \\
\text { harga jual ke pengepul dijual dengan } \\
\text { harga Rp. } 4.000 / \mathrm{kg} \text {. Selisih Rp. } 1.000 \\
\text { digunakan oleh pengurus bank } \\
\text { sampah untuk membeli minuman bagi } \\
\text { para pekerja. }\end{array}$ \\
\hline 3 & $\begin{array}{l}\text { Partisipasi } \\
\text { dalam sistem } \\
\text { online }\end{array}$ & $\begin{array}{l}\text { Sudah tergabung dengan sistem } \\
\text { online semenjak dari terbentuknya } \\
\text { bank sampah. Dari Dinas } \\
\text { Lingkungan Hidup langsung } \\
\text { diarahkan untuk bisa } \\
\text { menggunakan aplikasi dan } \\
\text { beberapa bank sampah sudah } \\
\text { didaftarkan ke dalam sistem } \\
\text { online tersebut (Smash). } \\
\text { Kendala yang sering terjadi } \\
\text { adalah lupa password dan tidak } \\
\text { paham penggunaan sistem online. } \\
\text { Secara fitur sudah diakui baik dan } \\
\text { lebih baik jika terdapat } \\
\text { pembaharuan atau update terkait } \\
\text { dengan jenis sampah karena } \\
\text { hingga saat ini belum terdapat } \\
\text { data sampah atau harga sampah } \\
\text { yang standar sesuai dengan jenis } \\
\text { sampahnya. Ketua Asosiasi } \\
\text { Pelapak dan Pengepul Indonesia } \\
\text { belum menemukan harga standar } \\
\text { penjualan dan pembelian sampah. }\end{array}$ & $\begin{array}{l}\text { Belum tergabung dengan aplikasi } \\
\text { Smash. }\end{array}$ \\
\hline 4 & $\begin{array}{l}\text { Intensitas } \\
\text { pengambilan } \\
\text { sampah }\end{array}$ & $\begin{array}{l}\text { Tergantung dari penyelesaian } \\
\text { pemilahan sampah di bank } \\
\text { sampah bisa per dua minggu atau }\end{array}$ & $\begin{array}{l}\text { Untuk pengambilan sampah oleh } \\
\text { pengepul setiap dua minggu sekali } \\
\text { atau kadang setiap satu bulan sekali }\end{array}$ \\
\hline
\end{tabular}


Planners InSight Vol. 2 No. No. 2, Agustus 2019 | ISSN 2615 - 7055

\begin{tabular}{|c|c|c|c|}
\hline No & $\begin{array}{l}\text { Variabel } \\
\text { Amatan }\end{array}$ & $\begin{array}{c}\text { Bank Sampah Permata RT } \\
\text { 01/RW } 011 \text { (Sudah Tergabung } \\
\text { dengan Sistem Online) }\end{array}$ & $\begin{array}{c}\text { Bank Sampah Permata RT 05/RW } \\
012 \text { (Belum Tergabung dengan } \\
\text { Sistem Online) }\end{array}$ \\
\hline & & $\begin{array}{l}\text { empat minggu sekali baru } \\
\text { diangkut oleh pengepul dengan } \\
\text { menghubungi pengepul atau } \\
\text { pengepul tersebut datang } \\
\text { langsung ke lokasi bank sampah } \\
\text { untuk penjemputan sampah. } \\
\text { Apabila sampah yang terkumpul } \\
\text { masih sedikit maka pengepul tidak } \\
\text { akan mengangkut sampah } \\
\text { tersebut dan akan balik lagi } \\
\text { apabila sampah sudah terkumpul } \\
\text { banyak. }\end{array}$ & $\begin{array}{l}\text { dan kemudian dipilah sendiri lalu } \\
\text { disetorkan. }\end{array}$ \\
\hline 5 & Mitra & $\begin{array}{l}\text { Mitra yang sejauh ini menjalin } \\
\text { kerjasama dengan bank sampah } \\
\text { adalah pengepul sampah, Eco } \\
\text { Village, Dinas Lingkungan Hidup, } \\
\text { Mitsubishi, Wulling, Smash. }\end{array}$ & $\begin{array}{l}\text { Mitra yang sejauh ini menjalin } \\
\text { kerjasama dengan bank sampah } \\
\text { adalah pengepul sampah, Eco } \\
\text { Village, Dinas Lingkungan Hidup, PT } \\
\text { Wulling. }\end{array}$ \\
\hline 6 & MoU/kerjasama & $\begin{array}{l}\text { MoU yang tersedia dari beberapa } \\
\text { mitra tersebut antara lain: } \\
\text { 1. } \\
\text { Mitsubishi dan wuling, kedua } \\
\text { perusahaan ini memiliki } \\
\text { MoU dalam memberikan } \\
\text { bantuan dana CSR } \\
\text { (Corporate social } \\
\text { responsibility), dengan } \\
\text { memberikan bantuan berupa } \\
\text { gerobak dan beberapa alat } \\
\text { kebersihan } \\
\text { Dinas lingkungan hidup dan } \\
\text { Eco village, lembaga } \\
\text { pemerintah melalui } \\
\text { komunitas pemerhati } \\
\text { lingkungan hidup ini memiliki } \\
\text { kerjasama diawal } \\
\text { pembentukan program bank } \\
\text { sampah dengan melakukan } \\
\text { sosialisasi dan memberikan } \\
\text { pelatihan kepada } \\
\text { kader/pengurus bank } \\
\text { sampah } \\
\text { Pengepul sampah memiliki } \\
\text { bentuk kerjasama sebagai } \\
\text { lembaga yang membeli } \\
\text { sampah dari pihak bank } \\
\text { sampah. } \\
\text { Smash - bertindak mirip } \\
\text { dengan pengepul sampah. }\end{array}$ & $\begin{array}{l}\text { MoU yang tersedia dari beberapa } \\
\text { mitra tersebut antara lain: } \\
\text { 1. } \\
\text { PT wuling, perusahaan ini } \\
\text { memiliki MoU dalam } \\
\text { memberikan bantuan dana CSR } \\
\text { (Corporate social responsibility), } \\
\text { dengan memberikan bantuan } \\
\text { berupa gerobak dan beberapa } \\
\text { alat kebersihan } \\
\text { 2. Dinas lingkungan hidup dan Eco } \\
\text { village, lembaga pemerintah } \\
\text { melalui komunitas pemerhati } \\
\text { lingkungan hidup ini memiliki } \\
\text { kerjasama diawal pembentukan } \\
\text { program bank sampah dengan } \\
\text { melakukan sosialisasi dan } \\
\text { memberikan pelatihan kepada } \\
\text { kader/pengurus bank sampah } \\
\text { 3. Pengepul sampah memiliki } \\
\text { bentuk kerjasama sebagai } \\
\text { lembaga yang membeli sampah } \\
\text { dari pihak bank sampah. }\end{array}$ \\
\hline 7 & $\begin{array}{l}\text { Saran } \\
\text { pengelolaan } \\
\text { sampah } \\
\text { berbasis online }\end{array}$ & $\begin{array}{l}\text { Harus ada pembaruan atau } \\
\text { update jenis sampah, belum ada } \\
\text { data sampah atau harga sampah } \\
\text { yang standar sesuai dengan jenis } \\
\text { sampahnya. Ketua Asosiasi } \\
\text { Pelapak dan Pengepul Indonesia } \\
\text { belum bisa menemukan harga } \\
\text { standar sampah. }\end{array}$ & $\begin{array}{l}\text { Berdasarkan pendapat dari pengurus } \\
\text { bank sampah, dalam proses } \\
\text { pendaftaran menjadi anggota Smash } \\
\text { memiliki kendala dalam hal birokrasi. } \\
\text { Proses dalam mengurus administrasi } \\
\text { cukup sulit akibat kurang nya } \\
\text { sosialisasi terkait dengan sistem. } \\
\text { Namun manfaat dari Sistem online ini }\end{array}$ \\
\hline
\end{tabular}




\begin{tabular}{|c|c|c|c|}
\hline No & $\begin{array}{l}\text { Variabel } \\
\text { Amatan }\end{array}$ & $\begin{array}{c}\text { Bank Sampah Permata RT } \\
\text { 01/RW } 011 \text { (Sudah Tergabung } \\
\text { dengan Sistem Online) }\end{array}$ & $\begin{array}{c}\text { Bank Sampah Permata RT 05/RW } \\
012 \text { (Belum Tergabung dengan } \\
\text { Sistem Online) }\end{array}$ \\
\hline & & & $\begin{array}{l}\text { sebenarnya cukup baik karena dapat } \\
\text { mempublikasikan dan } \\
\text { menghubungkan bank sampah } \\
\text { dengan masyarakat luas sehingga } \\
\text { bank sampah dapat lebih mudah } \\
\text { dikenal dan mendapat bantuan } \\
\text { seperti CSR maupun dana hibah. }\end{array}$ \\
\hline
\end{tabular}

Sumber: Hasil pengolahan, 2019

\section{v. KESIMPULAN}

a) Secara fisik, kondisi lingkungan bank sampah dan kondisi ruang pelayanan bank sampah antara bank sampah yang sudah dan belum tergabung dengan sistem online tidak memiliki perbedaan yang cukup signifikan.

b) Dalam sistem pembelian sampah, tidak terdapat perbedaan yang mencolok antara sistem pembelian sampah yang diterapkan oleh bank sampah yang sudah dan belum tergabung dengan sistem online. Perbedaan hanya terdapat pada 1 variabel amatan, yaitu terkait dengan peminjaman uang. Pada bank sampah yang telah terdaftar dengan sistem online di Smash, nasabah bank sampah dapat meminjam uang ke bank sampah. Nasabah juga bisa langsung mengambil uang hasil dari penukaran sampah. Sedangkan pada bank sampah yang belum bergabung dengan sistem online, belum ada sistem peminjaman uang, hanya mekanisme menabung saja.

c) Dalam sistem penjualan sampah, tidak terdapat perbedaan yang mencolok antara sistem pembelian sampah yang diterapkan oleh bank sampah yang sudah dan belum tergabung dengan sistem online. Perbedaan hanya terdapat pada 2variabel amatan, yaitu terkait dengan partisipasi dalam sistem online (Smash) yang berdampak pada semakin dikenalnya bank sampah jika sudah tergabung dengan sistem online. Dengan semakin dikenalnya suatu bank sampah, maka terdapat beberapa keuntungan diantaranya menghubungkan dan mendekatkan supply dan demand yaitu antara nasabah, bank sampah dan konsumen/pelanggan sampah serta perolehan dana hibah dan CSR yang lebih prospektif untuk bank sampah yang sudah bergabung dengan sistem online (Smah). Kendala yang ditemukan bagi bank sampah yang telah tergabung dengan sistem online Smash adalah lupa password dan kurang paham terkait skema dan sistem. Sedangkan alasan bank sampah yang belum bergabung dengan sistem online Smash adalah kesulitan dalam memenuhi persyaratan/birokrasi yang ditetapkan oleh Smash.

d) Beberapa perbedaan antara bank sampah yang sudah tergabung dengan sistem online Smash dan yang belum bergabung: (a) keberadaan fasilitator (tidak terdapat fasilitator pada bank sampah yang belum tergabung dengan sistem online); (b) kegiatan di luar jual beli sampah (kegiatan di luar jual beli sampah cenderung lebih banyak dan beragam untuk bank sampah yang telah tergabung dengan sistem online); (c) kegiatan pengolahan sampah (terdapat kegiatan pengolahan sampah seperti proses daur ulang sampah pada bank sampah yang telah tergabung dengan sistem online); dan (d) sistem bagi hasil (sistem bagi hasil sebesar 5\% antara antara bank sampah, nasabah dan pengepul pada bank sampah yang telah tergabung dengan sistem online).

\section{DAFTAR PUSTAKA}

e) Brantas News. 2018. 125 Komunitas Bank Sampah Kab.Bekasi, Lakukan Kegiatan di 23 Kecamatan dan 186 Desa. [Online]. Available:

https://www.berantasnews.com/125-

komunitas-bank-sampah-kab-bekasilakukan-kegiatan-di-23-kecamatan-dan186-desa_trashed/ (Diakses 2 Desember 2019).

f) Jambeck, J. R., Geyer, R., Wilcox, C., Siegler, T.R., Perryman, M., Andrady, A., Narayan, R., Law, K.L. 2015. Plastic Waste 
Inputs from Land into the Ocean. SCIENCE (347, 6223: 768-771).

g) Krippendorff, Klaus. 1993. Analisis Isi: Pengantar Teori dan Metodologi Edisi ke1. RajaGrafindo Persada: Jakarta.

h) Kementerian Lingkungan Hidup. 2012.Dari Sampah Membangun Ekonomi Kerakyatan; Profil Bank Sampah Indonesia 2012. KLHK: Malang.

i) Kementerian Lingkungan Hidup. 2014. From trash to cash. [Online]. Available: http://www.menlh.go.id.

j) KLHK. 2017. Kebijakan Bank Sampah dan Bank Sampah Induk dalam Pengelolaan Sampah. Presentasi Direktorat Pengelolaan Sampah Ditjen Pengelolaan Sampah, Limbah dan B3 Kementerian Lingkungan Hidup dan Kehutanan, Banjarmasin, 2 November 2017.

k) Kurnia, A.I., dan Romansyah, D. 2015. Rancangan Sistem Siklus Akuntansi pada Bank Sampah. Jurnal Akuntansi dan Keuangan Islam (3, 1: 39-55).

I) Peraturan Menteri Negara Lingkungan Hidup Republik Indonesia Nomor 13 Tahun 2012 tentang Pedoman Pelaksanaan Reduce, Reuse, dan Recycle melalui Bank Sampah.

m) Peraturan Pemerintah Nomor 81 Tahun 2012 tentang Pengelolaan Sampah Rumah Tangga dan Sampah Sejenis Sampah Rumah Tangga.

n) Smash. 2019. Sistem Online Manajemen Sampah-A Digital Solution for Urban Trash Problem.

o) Suryani, A.S. 2014. Peran Bank Sampah dalam Efektivitas Pengelolaan Sampah: Studi Kasus Bank Sampah Malang. Aspirasi (5,1: 71-84).

p) Undang-undang Nomor 32 Tahun 2009 tentang Perlindungan dan Pengelolaan Lingkungan Hidup.

q) Undang-undang Nomor 18 Tahun 2008 tentang Pengelolaan Sampah.

r) Undang-undang Nomor 10 Tahun 1998 dan Undang-undang Nomor 1 Tahun 2013 tentang Lembaga Keuangan Mikro.

s) Undang-undang Nomor 7 Tahun 1992 tentang Perbankan.

t) Unilever. 2013. Buku Panduan Sistem bank Sampah \& 10 Kisah Sukses. Yayasan Unilever Indonesia: Jakarta.

u) World Bank. 2014.Results-Based Financing for Municipal Solid Waste: Urban Development Series Knowledge Papers 91861 v2. Global Urban and DRM Unit, World Bank: Washington.

v) Wulandari, D., Utomo, S.H., Narmaditya, B.S. 2017. Waste Bank: Waste
Management Model in Improving Local Economy. International Journal of Energy Economics and Policy (7,3: 36-41). 